Article

\title{
Social Entrepreneurship in the Conduct of Responsible Innovation: Analysis Cluster in Mexican SMEs
}

\author{
Irene L. Bahena-Álvarez ${ }^{1, *}$, Eulogio Cordón-Pozo ${ }^{2} \mathbb{C}$ and Alejandro Delgado-Cruz ${ }^{3}$ (1) \\ 1 Doctorate in Economics and Business Administration, University of Granada, 18010 Granada, Spain \\ 2 ISDE Research Group, University of Granada, 18010 Granada, Spain \\ 3 Faculty of Tourism and Gastronomy, University of the State of Mexico, Toluca 50100, State of Mexico, Mexico \\ * Correspondence: lilibahena@yahoo.com.mx or lilibahena@correo.ugr.es
}

Received: 28 May 2019; Accepted: 3 July 2019; Published: 7 July 2019

\begin{abstract}
Responsible innovation combines philanthropic and economic aspects and it is common to refer to entrepreneurs who lead it as "social entrepreneurs". The present study of 100 Mexican small and medium-sized enterprises (SMEs), provides knowledge of an exploratory nature about what the models of organization are conducive to SMEs in the generation and development of responsible innovations. Through the statistical technique of cluster analysis, this study identified and characterized four models of organization according to the level of social entrepreneurship intentions reached: (1) "The techno-scientific organization", (2) "The techno-social organization", (3) "The capitalist-social organization" and (4) "The capitalist organization". While in Europe the dominant discourse about responsible innovation focuses on the control of the risk of social rejection of the advance of science and technology. In contexts, such as the Mexicans, the phenomenon is configured as the mechanism through which entrepreneurs articulate its technological and scientific capabilities to solve priority and specific problems of the society, however, the social impact does not crucially affect their business initiatives. The techno-scientific organization (50\% of studied SMEs) is proposed as the model of organization with greater viability for Mexican entrepreneurs.
\end{abstract}

Keywords: social entrepreneurship; responsible innovation; sustainable management; Mexican SMEs

\section{Introduction}

Business organizations seem to agree with the idea that its activity cannot ignore the expectations of different interest groups calling for ethical business with reputable business practices, covering new concepts of risk and of opportunity. Responsible Innovation (RI) is the concept that aims to collect the interaction between innovation and social values. It challenges a better understanding of the effects of human actions and how the multi-level innovation system affects society in general.

In most developed countries, the first attempts have emerged to promote and regulate the concept legally, designating a total budget of 91 million euros in support of research and implementation of responsible innovation [1]. However, the problem with the current concept of RI is that it is developed by researchers and policy makers [2] who are focused primarily on the conduct of responsible science and technological development [3] without differentiating between research, development and commercialisation [4]. This brings important challenges in the business context where documentation of its implementation is still scarce [5].

Even though it is difficult assuming that, small and medium-sized enterprises (SMEs) are willing to invest time, money and intellect to lead a responsible innovation, either creating new businesses or reformulating the current management of their businesses. However, several studies have endured 
that, by offering innovative solutions to multiple environmental and social problems, SMEs are being rewarded with profitability, new knowledge and talents [6], breadth of social capital [7] and attraction of new financial resources [8]. In Europe, as an example, SMEs may receive funding through grants, loans and guarantees to start responsible, generating entrepreneur projects of urban and regional development, employment, social inclusion, research, innovation and humanitarian aid [9]. Nonetheless, their interests and values may differ from researchers in academia or Research and Development departments.

While the concept RI is increasingly being studied the most in the field of large companies, RI in SMEs research has been dispersed across different disciplines and research communities such as the management of innovation, sustainable entrepreneurship, clean production, sustainable management, and more recently, social innovation [9]. There is a limited literature that defines the criteria and processes in the context of SMEs-related [8]. His speech has been tackled from two points of view: (1) as a tool that leads to SMEs towards sustainability, and (2) as a business opportunity to make social and environmental commitments.

An unambiguous definition of RI may be an unattainable issue in the responsible small innovative enterprises context, for this reason, this study adopts a working conceptualization for the purposes of this paper against a background of the terms, coming from different fields of knowledge. We conceive $\mathrm{RI}$ as an innovation that seeks to solve or reduce a social problem. In this way, it may capture a more fruitful perspective to conduct responsibility in SMEs. Since RI combines philanthropic and economic aspects, by demanding that the innovator should understand his responsibility and consequences of each innovation, it is common to refer to entrepreneurs who lead it as "social entrepreneurs". Social Entrepreneurship theory (SE) comprises a particular subset of entrepreneurial activity, wherein the products and services attempt to address social problems [10]. Drawing support from SE, the following study of 100 Mexican SMEs, attempts to be a pioneer in Latin America, addressing a topic quite interesting and relevant into RI in SMEs literature raising the following research question:

What are the organizational models through which SMEs lead responsible innovations?

To answer our research idea, this study aims to test a variety of motives associated with traditional entrepreneurship proposed by Shapero [11], antecedents which predict social entrepreneurial intentions identified by Mair and Noboa [10] and extended by a typology of organizations engaged in CSR-Driven Innovation by Hockerts et al. [12] with a sample of Mexican SME companies. This paper provides knowledge of exploratory nature on the existence of different paths for SMEs to achieve the challenge of IR within a nascent and understudied research area.

The rest of this paper is organized as following. First, a review of the literature of the theory of social entrepreneurship and responsible innovation in the context of SMEs is discussed. In the next section, the research method is described, followed by results that give rise to a discussion section, and finally, conclusions and possible lines of research which could enrich the field of knowledge are exposed.

\section{Theoretical Background}

\subsection{Creating New Businesses that Add Social Value}

The concept of social entrepreneurship (SE) emerged at the end of the 1990's in the United States [13-18] and in the United Kingdom [19-22]. However, recently it has been the subject of academic discussion [10,23-27].

$\mathrm{SE}$ includes different concepts for different people and research communities. One school of thought referred to SE as the management of scenarios to create social value [28,29]. A second group of researchers define SE as a socially responsible business involvement in practice [30,31]. Finally, a third line of thought describes it as an instrument to solve social problems and means of social transformation [32]. 
From Europe SE concepts were shaped under the influence of an intensive development of the third sector. The need for professional skills and effective management methods drove non-profits' structures to adopt business behaviour. As a result, laws were passed to promote new legal forms, for the development of the so-called new social economy or solidarity-based economy, which has inspired coalitions of actors for the last twenty years. Public schemes were designed to target more specific work integration social enterprise problems [33], e.g., "work integration social enterprises" (WISEs). The main objective of work integration social enterprises was to help lowly qualified unemployed people at risk of permanent exclusion from the labour market. WISEs integrated people into work and society through a productive activity [34].

By this manner, the concept of SE was systematically associated with such employment creation initiatives. Under the academic sphere, analytical efforts were undertaken at the conceptual and empirical levels especially by the EMES European Research Network, a major research program funded by the European Commission creating an initial set of economic and social indicators that proved to be a fairly robust and reliable conceptual framework. Such a list of indicators has formed a tool to locate the position of the observed entities relative to an "ideal-type" and eventually identify subsets of social enterprises. From the EMES perspective, social enterprises are not-for-profit private organizations which provide goods or/and services directly, related to their explicit aim to benefit the society. In general, they involve several types of stakeholders in their governing bodies, placing a high value on their autonomy and bearing economic risks under their operation. Thereon, a recent comparative analysis of the various Mexican forms in terms of EMES indicators demonstrated that, the social sector of the economy includes some types or organizations that cannot be considered as social enterprises, although they have been part of historical processes or exercise political pressure to be considered as social economy organizations and can be eligible to receive public funds. These findings allowed one to conclude that there is no clear definition or theory of social enterprises and the social economy in Mexico [35].

From the US scene, SE debate has been driving by key actors such as foundations and business schools. Prominent expressions of this emergence were the launching, in 1993, of a "Social Enterprise Initiative" by the Harvard Business School and a group of business executives as the "Alpha Centre for Social Entrepreneurs". Other organizations, such as Echoing Green and Ashoka, began to adopt officially the term "social entrepreneurs", while new funds dedicated to the latter were set up as, for instance, by Youth Service America, in 1994. Similarly, social entrepreneurs in Canada were invocated as individuals who bring about systemic change by influencing social behavior for the good on a global scale [36].

The US landscape of SE was the social mission. Under the "earned income" school of thought, from this view, organizations might target the "commercial non-profit approach", as they allocate any profit to the fulfilment of a social mission. On the other hand, as for the "social innovation school", the second school of thought, SE dynamics are embedded in companies which may be either non-profit or for-profit but, whatever the type of organization, the innovation process is primarily oriented to social change. Since the 1990s, various activities undertaken by for-profit firms to assert their corporate social responsibility began to be considered, by some authors, as part of the spectrum of social entrepreneurship [13,37]. Such an approach might lead one to consider any social value generating activity as belonging to the wide spectrum of social entrepreneurship, even if this activity remains marginal in the firm's overall strategy [33] (p. 16). There is no clear dimensionalisation of the SE construct that enjoys general support, which makes it hard to capture the heterogeneity of a unit of analysis in terms of its key characteristics that have relevant implications for outcomes [38] (p. 211). The absence of an agreed-on definition and dimensionalisation of the SE construct explains the widely differing operationalization in the empirical SE literature. Most research is based on case studies and success stories of successful social entrepreneurs in a single country. Nonetheless, from SE defined as "entrepreneurial activity" with the explicit objective to address societal pains, was developed by Lepoutre et al. [39] a methodology called Global Entrepreneurship Monitor (GEM) to target the first 
theory-based data collection approach for social entrepreneurial activity on a global scale, enabled from 49 countries across the world and their comparisons on social entrepreneurship, arising from three different dimensions: social mission, innovativeness and revenue model.

With such a heterogeneity in approaches, the literature lacks cumulative insights that could help social entrepreneurship research to progress more rapidly and more effectively [40]. Much of the nascent social entrepreneurship literature that has focused on understanding the characteristics of individual social entrepreneurs, focusing on their noble intentions, [41,42] their goals, identity, and values [43] or the missions of their associated organizations [44]. These studies often assume that firms that claim to address social problems are more likely to achieve these missions or are more compassionate and well intentioned [41] than traditional market-focused organizations.

Nonetheless, there are studies that examine the measurement of the outcomes resulting from pro social behaviour, as the defining element of social entrepreneurship [36,45]. From this perspective, there are four different approaches for conceptualizing and measuring social impact [40].

Some papers compare Activities across Multiple-sectors suggesting that scholars tend to view social impact as a generalizable construct that can only be compared between organizations operating in very similar contexts. In this term, researchers e.g., Liston-Heyes and Ceton [46], rely on ratings data that have been developed by private organizations (i.e., KLD/MSCI, EIRIS, ASSET4, etc.). In contrast, other authors e.g., Salazar et al. [47] explore factors assumed to contribute to social impact within a single industry and/or among a population of organizations pursuing similar pro social initiatives driving a Single-Sector Activity approach. Others conceptualize social impact as an outcome that can be measured and compared across multiple contexts adopting a Multi-Sector Outcome approach, connecting social impact to existing practices or theories, including stakeholder and economic utility theories [48]. On the other hand, Single-Sector Outcome approach to social impact focuses on considering one or more types of social outcomes in a specific context, driven by the assumption that the outcomes in each sector are unique and, therefore, difficult or impossible to compare with those in other sectors, e.g., Brickson [49].

\subsection{Responsible Innovation: New Contract between Science, Technology, Innovation and Society}

Innovation is a multidimensional process whereby organizations transform ideas into new or improved products, services or processes, to grow, compete and differentiate themselves successfully in their markets [50]. Despite being designed as a business tool to achieve growth and economic prosperity, it is not a completely virtuous concept. Through the theories of innovation management, the concept has evolved to finding space for the recognition within the scientific, business and political communities of the importance of adding ethical considerations and including social concerns between the innovation process and adoption of new technologies. As a result of discussion of the public rejection in recent advances in the field of nanotechnology, the EU focused its public policy on the notion of the concept RI [51], to support projects for research and innovation through the Horizon 2020 program.

Although the academic discussion of the impact on society of the advancement of science and technology is not a new theme, there is a recent interaction of a research community that aims to join, strengthen and criticize the prospects of the role of responsibility in the research and the process of scientific development, to solidify its elements and implications in academic and industrial laboratories. A clear attempt in this way is the scientific publication Journal of Responsible Innovation (JRI), whose first issue, was reported at the beginning of 2014 and which has presented texts focused on the concept of RI and its institutionalization. A widely quoted definition of RI is the proposal by Von Schomberg [52] (p. 50), who define RI as: interactive and transparent process by which societal actors and innovators become mutually responsive to each other with a view to the (ethical) acceptability, sustainability and societal desirability of the innovation process and its marketable products. For his part, Stilgoe et al. [53] distinguish four dimensions to the government's science, innovation and institutionalization of the concept: (1) inclusion, (2) anticipation, (3) responsiveness and (4) reflexivity. 
About $90 \%$ of RI research has been published from the year 2011, coming from various disciplines such as: science, technology, engineering, computer and information technology, innovation, sociology, psychology, politics, ethics and business [54]. Initially, the empirical research was focused on topics of nanotechnologies, geo-engineering, biomedical technologies, public involvement and dialogue processes. However, the research has expanded its focus with business themes such as adoption and implications of IR organizations [55], academic spin-offs [56], SMEs [57], implementation of RI in finance [58-60] and the automotive sector [61]. It can be assumed that the RI concept involves a set of assumptions that make it a concept of a multidisciplinary nature: (1) focus on research and product innovation to benefit society and environment; (2) involvement of society in the early stages of the innovation process, including non-governmental groups as spokespersons of the public value; (3) evaluation and effective prioritization of social, ethical and environmental impacts at all stages of the innovation process; (4) regulatory mechanisms to anticipate and handle problems and opportunities, and give immediate response to adverse circumstances, and (5) openness and transparency as integral components of the research and innovation process.

There is a limited literature that defines the processes and criteria related to the RI in the context of SMEs [8]. Responsible innovation in SME research, has been dispersed across different disciplines and research communities, such as the management of innovation, sustainable entrepreneurship, clean production, sustainable management, and more recently, social innovation [9]. From the line of thought of sustainable management, there are terms proposed to define an innovation that seeks to solve a social or environmental problem as: sustainable development innovation [62], sustainable innovation [63,64], CRS-driven innovation [12], innovation related to sustainability [65], sustainability-oriented innovation [8] and responsible innovation [57].

Following this line of argumentation, based on a conceptual analysis of literature reviews on responsible and sustainable innovation, Lubberink et al. [66] came to the conclusion that sustainable innovation overlaps conceptually with responsible innovation. Furthermore, sustainable innovation increasingly addresses complex challenges which require the development of complex systems-shaping solutions. Adams et al. [67] state that these solutions require workable relationships with a complex network of stakeholders who enable engagement in a dialogue, to gain legitimacy, to acquire necessary knowledge and to find opportunities for responsive solutions. Sustainable and responsible innovations are both focused on sustainability as a desirable outcome of innovation [66,67]. Studies regarding green and eco innovation research are primarily focused on the environmental and economic dimensions as innovation outcomes [68]. However, sustainable innovation responds to the 'triple-bottom-line' and increasingly integrates the social dimension of sustainability in innovation processes and subsequent outcomes as well [67]. Therefore, it can be concluded that responsible innovation and sustainable innovation not only take the economic and environmental dimension into account as innovation outcomes but also the social dimension [5]. Corporate sustainable innovation has already received considerable attention from researchers, managers, and policy makers [67]. Due to the conceptual overlap, and the fact that sustainable innovation is already widely documented in the business context, studies on sustainable innovation can serve as important resources for studying responsible innovation practices in the business context [5].

\subsection{Reasons Influencing Social Entrepreneurship}

As part of the effort to provide an integral concept of SE, the researchers Mair and Marti [10] (p. 37) defines it as: a process of creation of value by combining resources in an innovative way to produce opportunities for social change, satisfying social needs.

Mair and Noboa were the first to advance theoretical propositions about four antecedents of social entrepreneurial intentions. Their idea has been discussed by Tukamushaba, Orobia and George [69] who have tested all variables and hypothesis suggested by the model to an international context. By now, a few exercises at empirical verification have been conducted. Forster and Grichnik [70] have applied it in context of corporate volunteering, finding support for Mair and Noboa model. Some 
studies have indirectly tested some of the Mair and Noboa hypothesis such as Ernst [71] finding partial support with the propositions from Mair and Noboa model. Other studies have extended the Mair and Noboa model such as Hockert [72] by adding prior experience with social organizations as a new antecedent. The results of all three samples provide strong evidence that individuals with prior experience of social issues tend to have higher social entrepreneurial intentions. This effect is mediated by the four variables suggested by Mair and Noboa.

To be able to answer our research idea, this study aims to test a variety of motives associated with traditional entrepreneurship proposed by Shapero [11], antecedents which predict social entrepreneurial intentions identified by Mair and Noboa [10] and extended by a typology of Organizations engaged in CSR-Driven Innovation Hockerts et al. [12] with a sample of Mexican SME companies located in the North, Centre and South of the country, it was determined to identify and characterize groups of companies according to the level of social entrepreneurial intentions that played a role in the development of responsible innovation. The study proposes the following research question.

What are the organizational models through which SMEs lead responsible innovations?

Traditional entrepreneurship literature considered two traditional prerequisites in the process of creating a business venture [11].

(1) Perceived desirability

(2) Perceived feasibility

However, in the literature of Social Entrepreneurship, Mair and Noboa, [10] argue that entrepreneurs aspiring to social change are influenced also by additional values.

(3) Emotional empathy

(4) Cognitive moral development

In this context, while around the world there are people with the characteristics necessary to innovate responsibly, a few make concrete decisions to undertake a sustainable business. For this reason, Mair and Noboa, [10] propose to add two elements to the personality of a social entrepreneur.

(5) Self-efficacy

(6) Social support

Based on these characteristics and their level of influence on the personality of the social entrepreneur, Hockerts et al. [12] propose to define three profiles:

The activist entrepreneur: It is defined as the type of entrepreneur who has the ability to "feel the pain" of people and the environment. Personal experience from unjust causes is channelled as inspiration to engage in social adventures, which proclaims its ideas and commitments to contribute to the construction of a world better.

The social technopreneur: This profile defines the enthusiasm to study, develop and implement a technology that adds value to society. Their main motivation is the belief that social problems can be solved with appropriate technological arrangement. Emotional empathy does not affect their motivation, however, social problems can be, a source that have an impact on their creativity and development of sophisticated technologies.

The social venture capitalist: Refers to "entrepreneurs with extensive knowledge in business". Their main motivation is "the market". They commit themselves to launching social business, convinced that the market calls for goods and services that positively impact society. Their performance is measured by the return on investment from their innovations. Social venture capitalist entrepreneurs, are more willing to accept vocational guidance and support of social investors and business incubators.

On the other hand, Hockerts et al. [12] suggest that there are different approaches to drive an innovation that generates a social value. These approaches explain what entrepreneurs intend to achieve, prioritize, and their means used to achieve their goals, defining three types of organizations (Figure 1). 


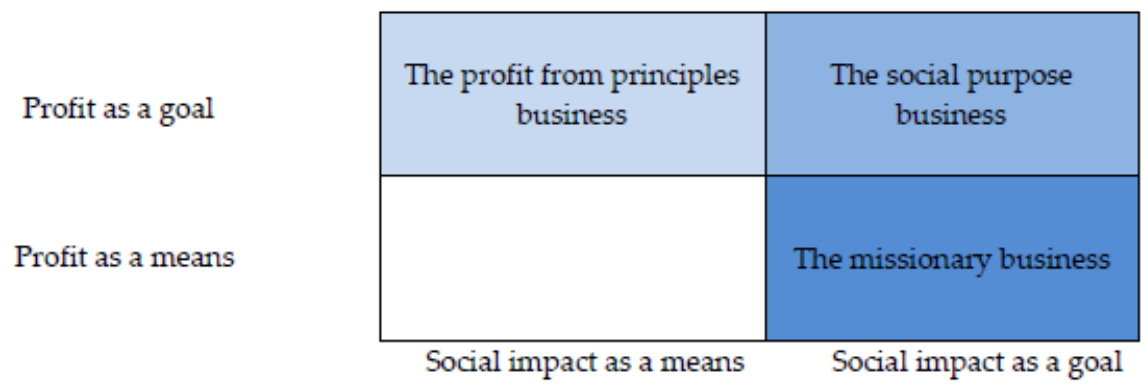

Figure 1. Typology of CSR-driven innovation business ventures by Hockerts et al. [12]. CSR: Corporate Social Responsibility.

\section{Methodology}

Due to the increasingly competitive global economy and labour market, Mexico has been giving great importance to the increase in the number of students and researchers in the areas of science and engineering. In 2016, a quarter of people aged 25 to 64 years with higher education had title in any of the areas of science, technology, engineering and math (STEM), equal to the average of OECD $(25 \%)$. However, recently, the new students to these areas of study, have exceeded the OECD average. In 2015, $32 \%$ of the new students at higher education chose areas related to science, technology, engineering and math (STEM), ratio that is among the first four countries in the OECD and 5 percentage points above the OECD average that is $27 \%$. Employment rates are adjusted to this new trend and are highest among adults with higher education who studied in the area of information, technology and communication (ICT), engineering, manufacturing and construction (83\%) field, which is greater than business, administration and law (80\%) [73].

Apart from that environments characterized by resources scarcity often experience an abundance of social problems and thus an increased demand for SE [44,74]. Similarly, countries with a lack of government support for social programs experience higher demand for SE [75]. On the other hand, the main previous research on RI in SMEs has been completed mostly in England, United States and India [9]. In these terms, result particularly interesting as well as useful, to focus this study to an environment where may be genuinely requested.

Personalities behind RI may vary considerably. However, entrepreneurs all share two traditional characteristics that entrepreneurial literature considers essential requirements in the process of entrepreneurial activity. They feel a desire to achieve a certain outcome "perceived desirability" and they consider it feasible to reach that outcome "perceived feasibility" [11]. Nonetheless, Mair and Noboa [10] point out, social entrepreneurs are driven by different values than traditional business entrepreneurs. Social entrepreneurs have to understand the needs and pain of other people and to feel sympathy for them "emotional empathy". Moreover, they also have the cognitive ability to choose what is morally right and wrong, "cognitive moral development". From this approach, anybody can be a social entrepreneur, even so, many well-citizens never take action because they do not believe their actions can transform society. Only people with a strong belief in their own capabilities and abilities will assume that their actions can solve or reduce actual social problems "self-efficacy". The conviction that change is feasible can be encouraged by systems such as networks of entrepreneurs "Social Support".

While Mair and Noboa model, assume that all four elements (emotional empathy, cognitive moral development, self-efficacy and social support) are indeed present in personalities who have conducted a social business. Hockets, et al. [12] support that there are sub-groups of social entrepreneurs, describing three profiles - Activist Entrepreneur, Social Venture Capitalist and Social Technopreneur. In turn, as a result of conducting their goals and means, social entrepreneurs form three types of organizations: the missionary business, the social purpose business and the profit from principles business. 


\subsection{Sample and Data Collection}

Unable to study to all Mexican companies, this study chose a non-probabilistic sample and the technique by voluntary respondents. The databases of the national registry of institutions and scientific companies and technology (RENIECYT), Venture Institute and the directory of hatcheries of the University of the State of Mexico, were used because their relevance for having the information necessary on economic entities. From these databases, were selected a cluster of 988 SMEs which the information of each SME was verified on official pages of Facebook and their Internet portals in order to obtain a representative number of companies involved in responsible innovation. Thus, e-mail was the mechanism used to invite to 908 companies; it was the link for access to the measurement instrument.

The period of data collection covered the months from January to July 2017. Interested firms delivered their answers, achieving a participation rate of $12.55 \%$. However, we used control questions to identify those who acknowledged that they had used responsible innovation, in other words, new improved products (goods and services), or a business model whose implementation resolves an environmental or social problems $[57,76]$. In this way, the final sample for this study is composed of 100 SMEs ( $88.64 \%$ of respondents).

\subsection{Instrument}

All items in our instrument take previous literature as their point of reference. The sections of "social entrepreneurship" (section a) and "General information" (section f) from survey data were used. In the first paragraph, items were located to estimate the degree of social entrepreneurship intentions (Table 1), at the same time, items were evaluated through a scale Likert type of seven points, where (1) was "extremely poor" and 7 "excellent" (Table 2).

Table 1. Items motivate social entrepreneurship.

\begin{tabular}{|c|c|c|c|}
\hline Orientation & Code & Author & Item \\
\hline Perceived Desirability & ES_01 & Shapero y Sokol, 1982 & $\begin{array}{l}\text { The main reason which prompted } \\
\text { us to create our responsible } \\
\text { innovation was the desire to create a } \\
\text { transformation in society using our } \\
\text { extensive knowledge of business. }\end{array}$ \\
\hline Perceived Feasibility & ES_02 & Shapero y Sokol, 1982 & $\begin{array}{l}\text { From the beginning, we had the } \\
\text { conviction of the social change that } \\
\text { we could generate with our } \\
\text { innovation, it was feasible. }\end{array}$ \\
\hline Emotional Empathy & ES_03 & Mair y Noboa, 2006 & $\begin{array}{l}\text { Our innovation arose from the } \\
\text { primordial desire to mitigate the } \\
\text { pain of people or nature. }\end{array}$ \\
\hline $\begin{array}{l}\text { Cognitive moral } \\
\text { development }\end{array}$ & ES_04 & Mair y Noboa, 2006 & $\begin{array}{l}\text { We believed that it was our } \\
\text { responsibility to create new } \\
\text { solutions to attack social problems, } \\
\text { not to do so, our morality would be } \\
\text { questioned. }\end{array}$ \\
\hline Self-efficacy & ES_05 & Mair y Noboa, 2006 & $\begin{array}{l}\text { We feel enthusiasm for further study } \\
\text { and to implement a technology that } \\
\text { produces a benefit to society. }\end{array}$ \\
\hline Social Support & ES_06 & Mair y Noboa, 2006 & $\begin{array}{l}\text { We were encouraged by the success } \\
\text { stories of other innovations and } \\
\text { networks of entrepreneurs. }\end{array}$ \\
\hline
\end{tabular}


Table 2. Scale of assessment of social entrepreneurship intentions.

\begin{tabular}{ccccccc}
\hline $\mathbf{1}$ & $\mathbf{2}$ & $\mathbf{3}$ & $\mathbf{4}$ & $\mathbf{5}$ & $\mathbf{6}$ & $\mathbf{7}$ \\
\hline--- & -- & - & -+ & + & ++ & +++ \\
\hline $\begin{array}{c}\text { Is not carried } \\
\text { out (is null) } \\
0 \%\end{array}$ & $\begin{array}{c}\text { Is not carried } \\
1 \%-14.28 \%\end{array}$ & $\begin{array}{c}\text { Is not carried } \\
14.29 \%-42.85 \%\end{array}$ & $\begin{array}{c}\text { Is performed } \\
\text { more or less } \\
42.86 \%-57.13 \%\end{array}$ & $\begin{array}{c}\text { Is performed } \\
57.14 \%-71.41 \%\end{array}$ & $\begin{array}{c}\text { Is performed } \\
71.42 \%-85.70 \%\end{array}$ & $\begin{array}{c}\text { Is performed } \\
\text { always } \\
85.71 \%-100 \%\end{array}$ \\
\hline $\begin{array}{c}\text { Extremely } \\
\text { poor }\end{array}$ & Too poor & Poor & Regular & Good & Very good & Excellent \\
\hline
\end{tabular}

With respect to the construct of social entrepreneurship intentions, items were subjected to a reliability test to analyse internal consistency using the Cronbach's alpha $(\alpha)$. As shown in Table 3, a value of 0.810 was obtained, exceeding the minimum of 0.700 recommended in the literature [49].

Table 3. Reliability of the construct of social entrepreneurship intentions.

\begin{tabular}{cccccc}
\hline Code & $\begin{array}{c}\text { Average Scale } \\
\text { if the Item } \\
\text { Has Been } \\
\text { Deleted }\end{array}$ & $\begin{array}{c}\text { Variance of } \\
\text { Scale if the } \\
\text { Item Has } \\
\text { Been Deleted }\end{array}$ & $\begin{array}{c}\text { Total } \\
\text { Correlation } \\
\text { of Elements } \\
\text { Corrected }\end{array}$ & $\begin{array}{c}\text { Cronbach's } \\
\text { Alpha if Item } \\
\text { Has Been } \\
\text { Deleted }\end{array}$ & $\begin{array}{c}\text { Construct } \\
\text { Cronbach's } \\
\text { Alpha }(\boldsymbol{\alpha})\end{array}$ \\
\hline ES_01 & 26.93 & 44.470 & 0.683 & 0.756 & Social \\
ES_02 & 26.62 & 44.985 & 0.674 & 0.759 & 0.810 \\
ES_03 & 26.77 & 44.300 & 0.647 & 0.763 & entrepreneurship \\
ES_04 & 27.38 & 44.884 & 0.515 & 0.793 & intentions \\
ES_05 & 26.37 & 46.074 & 0.622 & 0.834 & \\
ES_06 & 27.53 & 47.383 & 0.362 & & \\
\hline
\end{tabular}

Additionally, to determine if the scale of measurement of Social Entrepreneurship intentions is valid and reliable, the confirmatory factor analysis (CFA) technique was used. Analysis was performed using Mplus statistical package $[77,78]$. Since in the model analysed indicators are ordinal in nature, we used the WLSMV (weighted least square mean and variance adjusted) estimator available in Mplus software, which is a robust estimator recommended when analysing ordered categorical data [79]. The WLSMV estimator was developed by Muthén, du Toit and Spisic [80] and it was designed specifically to be used with small and moderate sample sizes.

Following recommendations of the literature on validation technique using CFA, we calculated Construct Reliability (CR) and Average Variance Extracted (AVE) for scale [81]. Values close to or above 0.700 for composite reliability and 0.500 for average extracted variance were used as indicators of the internal consistency of the scales (in the case of the scale analysed, CR had a value of 0.868 while AVE reached 0.535). The criterion of all factor loadings being significant $(p<0.050)$ was used as indicator of convergent validity [82].

Regarding indicators of goodness of fit for model, Table 4 shows the results obtained after estimating the model. These results allow us to affirm that the scale used is valid and reliable.

On the other hand, the "General information" section included a section of questions to better describe attributes that may occur in the form of social entrepreneurship intentions (Table 5) and another section sector (SECT), economic activity (ACT_ECON), state (STATE), city (CITY), is a legal (FORM_JUR), year of operation (YEAR_OPE) and number of workers (NUM_WORK) of the company for their characterization. 
Table 4. Model fit information.

\begin{tabular}{cc}
\hline Indicator & Results \\
\hline & Value (WLSMV estimator) $=14.892$ \\
Chi-square test of model fit & $\begin{array}{c}\text { Degrees of freedom }=9 \\
\text { P-value }=0.0940\end{array}$ \\
\hline & Estimate $=0.080$ \\
RMSEA (Root Mean Square Error of Approximation) & 90 Percent C. I. 0.000; 0.151 \\
& Probability RMSEA $\leq 0.050=0.216$ \\
\hline CFI & 0.991 \\
TLI & 0.985 \\
SRMR (Standardized Root Mean Square Residual) & 0.028 \\
Cronbach's $\alpha$ & 0.810 \\
McDonald's $\omega$ & 0.831 \\
\hline
\end{tabular}

Table 5. Questions of characterization of small and medium-sized enterprises (SMEs).

\begin{tabular}{|c|c|c|c|}
\hline Code & Question & Scale & Answer \\
\hline INN_MOT & $\begin{array}{l}\text { What is the primary } \\
\text { motivation that leads } \\
\text { them to responsible } \\
\text { innovation? }\end{array}$ & Nominal & $\begin{array}{l}\text { 1. No answer. } \\
\text { 2. Economic result: We define to measure } \\
\text { our performance as the economic } \\
\text { performance and return on investment. } \\
\text { 3. Social result: The most that motivates us } \\
\text { is to disseminate our ideas better than } \\
\text { protect them, for us the social impact is the } \\
\text { central point of our success. } \\
\text { 4. Technological result: Motivates us to } \\
\text { know that we have helped to solve a social } \\
\text { problem with the optimal } \\
\text { technological arrangement. }\end{array}$ \\
\hline INC_SUPP & $\begin{array}{l}\text { Have you received } \\
\text { support for the business } \\
\text { incubation of responsible } \\
\text { innovation? }\end{array}$ & Dichotomy & $\begin{array}{l}\text { 1. Yes } \\
\text { 2. No }\end{array}$ \\
\hline FINAN_RES & $\begin{array}{l}\text { Have you seen any } \\
\text { improvement of financial } \\
\text { results by the } \\
\text { implementation of } \\
\text { responsible innovation? }\end{array}$ & Ordinal & $\begin{array}{l}\text { 1. Too much } \\
\text { 2. Not much } \\
\text { 3. Nothing }\end{array}$ \\
\hline RES_METH & $\begin{array}{l}\text { Do you have any method } \\
\text { to measure the result of } \\
\text { responsible innovation? }\end{array}$ & Dichotomy & $\begin{array}{l}\text { 1. Yes } \\
\text { 2. No }\end{array}$ \\
\hline ENT_ASOC & $\begin{array}{l}\text { Are you a member of a } \\
\text { chamber or business } \\
\text { association? }\end{array}$ & Dichotomy & $\begin{array}{l}\text { 1. Yes } \\
\text { 2. No }\end{array}$ \\
\hline QUA_REC & $\begin{array}{l}\text { Do you have any } \\
\text { recognition of quality? }\end{array}$ & Dichotomy & $\begin{array}{l}\text { 1. Yes } \\
\text { 2. No }\end{array}$ \\
\hline SUPP & $\begin{array}{l}\text { Are you a supplier of } \\
\text { large enterprises? }\end{array}$ & Dichotomy & $\begin{array}{l}\text { 1. Yes } \\
\text { 2. No }\end{array}$ \\
\hline EXPOR & $\begin{array}{l}\text { Does the company } \\
\text { export activities? }\end{array}$ & Dichotomy & $\begin{array}{l}\text { 1. Yes } \\
\text { 2. No }\end{array}$ \\
\hline
\end{tabular}




\subsection{Statistics Assessment}

The cluster analysis, was used for the processing of data a statistical technique to classify elements where each of them is similar to others in the same group (homogeneity or internal coherence), but different to the elements belonging to other groups (heterogeneity or external isolation) [83,84].

A hierarchical test data obtained from the construct of social entrepreneurship intentions was used. As a group of similar objects procedure opted for the method of Ward, seeking to minimize the sum of errors between the two groups with respect to all variables [85]. As a measure of dissimilarity between the groups, the Euclidean squared distance was used between each pair of observations, where the shorter distances indicated greater similarity [84]. Finally, was spread the ANOVA F test to verify the reliability of the cluster solution.

The analysis of the clusters obtained was carried out from the history of conglomeration and dendrogram, as well as the descriptive statistics (means $\widetilde{x}$ and standard deviations $\sigma$ ). The treatment of data supported the software SPSS version 25 (International Business Machines Corporation-IBM, Armonk, NY, USA).

\section{Analysis of Results}

\subsection{Sample Characterization}

Mexican companies from the study, operate mostly (50\%) in four cities in the Centre of the country (city of Mexico, Queretaro, State of Mexico and Puebla), the other half is diversified in the North and South of the Mexican Republic. There are also entities engaged in economic activities of food and health (16\%), information (15\%), industry (12\%) and services (13\%). In terms of antiquity, $79 \%$ are young-adult companies (11 to 20 years), $7 \%$ new businesses ( 1 to 3 years), $5 \%$ young entrepreneurs (4 to 10 years), $5 \%$ (21 to 50 years) adult companies and $4 \%$ mature companies (over 51 years).

By its legal form, 57\% rule as a limited company, $11 \%$ limited companies promoter of investment, $11 \%$ limited liability companies, $9 \%$ individuals with business activities, $6 \%$ civil association and the remaining $6 \%$ incorporation prosecutor, cooperative society and popular financial company. The number of workers [86], $42 \%$ are micro, medium $28 \%$ and $27 \%$ small (Table 6 ), so they are faithful representative of SMEs.

Table 6. Companies by size according to the number of workers.

\begin{tabular}{cccc}
\hline Size & Sector & Range of Number of Workers * & Percentage \\
\hline Micro-size & All & Until 10 & 42 \\
\hline \multirow{2}{*}{ Small-size } & Shop & Until 11 to 30 & 0 \\
& Industry and Services & Until 11 to 50 & 27 \\
\hline \multirow{2}{*}{ Medium-size } & Shop & Until 31 to 100 & 0 \\
& Services & Until 51 to 100 & 28 \\
& Industry & Until 51 to 250 & 2 \\
\hline & Missing value & 1 \\
\hline & Total & 100 \\
\hline
\end{tabular}

\subsection{Clusters According to Social Entrepreneurship Intentions to Drive Responsible Innovation}

Reading of the dendrogram is evident the presence of two clusters defined from the point of the graphic view (Appendix A). However, assuming distances from conglomeration history and the purpose of the study, was decided to make a cut in the 93 stage, to obtain four clusters that would describe and differentiate better Mexican companies that lead a responsible innovation. This decision was supported by the ANOVA F test to find differences highly selectable between the identified cluster $(p \leq 0.010)$. 
As can be seen in Table 7, in general, Mexican companies were valued as "good" social entrepreneurship $(\widetilde{x}=5.38 ; \sigma=1.32)$, however, there are differences in the estimates between each identified cluster. According to the information contained in Table 6, cluster 1 is the highest level of social entrepreneurship $(\widetilde{x}=6.19 ; \sigma=0.65)$, characterized by SMEs motivated by their conviction to social change and their inspiration from other activists in order to decrease the social and environmental problems through the optimal use of technologies and in addition to being aware that ethical factors should guide their actions.

Table 7. Appreciation of social entrepreneurship intentions by each cluster of SMEs.

\begin{tabular}{|c|c|c|c|c|c|c|c|c|c|c|c|}
\hline \multirow[t]{2}{*}{ Item } & \multicolumn{2}{|c|}{$\begin{array}{c}\text { Cluster } 1 \\
(n=50)\end{array}$} & \multicolumn{2}{|c|}{$\begin{array}{c}\text { Cluster } 2 \\
(n=21)\end{array}$} & \multicolumn{2}{|c|}{$\begin{array}{c}\text { Cluster } 3 \\
(n=19)\end{array}$} & \multicolumn{2}{|c|}{$\begin{array}{c}\text { Cluster } 4 \\
(n=10)\end{array}$} & \multirow{2}{*}{$\begin{array}{c}\text { ANOVA } \\
F\end{array}$} & \multicolumn{2}{|c|}{$\begin{array}{c}\text { General } \\
(n=100)\end{array}$} \\
\hline & Average & $\mathrm{DE}$ & Average & DE & Average & DE & Average & DE & & Average & DE \\
\hline ES_01 & 5.96 & 1.277 & 5.95 & 1.396 & 4.84 & 1.463 & 2.40 & 1.174 & $22.236^{* *}$ & 5.39 & 1.705 \\
\hline ES_02 & 6.32 & 0.913 & 6.67 & 0.577 & 4.84 & 1.573 & 2.20 & 1.033 & $55.181 * *$ & 5.70 & 1.673 \\
\hline ES_03 & 6.30 & 0.953 & 6.67 & 0.577 & 3.79 & 1.873 & 2.80 & 1.229 & $62.942^{* *}$ & 5.55 & 1.789 \\
\hline ES_04 & 5.68 & 1.463 & 5.95 & 1.161 & 2.79 & 1.475 & 3.20 & 2.700 & $55.683^{* *}$ & 4.94 & 2.019 \\
\hline ES_05 & 6.52 & 0.909 & 6.76 & 0.539 & 5.53 & 1.307 & 2.20 & 1.619 & $58.041^{* *}$ & 5.95 & 1.666 \\
\hline ES_06 & 6.36 & 0.875 & 2.62 & 1.203 & 4.16 & 2.062 & 2.70 & 2.359 & $91.164^{* *}$ & 4.79 & 2.171 \\
\hline ES & 6.190 & 0.654 & 5.769 & 0.495 & 4.324 & 0.565 & 2.583 & 0.813 & $45.124^{* *}$ & 5.386 & 1.321 \\
\hline
\end{tabular}

Moreover, cluster 2 is characterized by a high score in their items, even with values higher and convergent compared to those obtained by cluster 1 . However, the difference lies in that, cluster 2 is not inspired by the success stories of innovations and networks of entrepreneurs $(\widetilde{x}=2.62 ; \sigma=1.20)$.

In cluster 3, we observe that social entrepreneurship is in a halfway point $\widetilde{x}=4.32 ; \sigma=0.56)$, meaning that to build or develop a responsible innovation, the desire for social benefit comes into the study and implementation of technology, since there is a conviction for social transformation. In these terms, this is a group of companies that do not care about their morality $(\widetilde{x}=2.79 ; \sigma=1.47)$, and is not moved by the decrease of socio-environmental problems $(\widetilde{x}=3.79 ; \sigma=1.87)$.

Cluster 4 is characterized for having a "poor" social entrepreneurship $(\widetilde{x}=2.58 ; \sigma=0.81)$, lack of motivation to change and social commitment, inferring that they are conducted under other aspects that are not included in this study, but they exist in the Mexican sector.

In terms of approaches that can explain what entrepreneurs intend to primarily achieve and the means used to obtain their goals (Table 8), it may be said that the main reason to conduct responsible innovations are the technological results (47\%), followed by the economic (37\%) and finally, the social $(14 \%)$. Also, $62 \%$ of these SMEs have received some resources or support their responsible innovations while impact on the financial results is visible in $94 \%$ of the entities $(64 \%$ with $30 \%$ with few and quite a few results). In contrast, $60 \%$ of the SMEs have mechanisms or methods for measuring the results of innovations, implying that it is only for those who have been supported and have been benefited by their results.

Clusters 1 and 2, share the same technological motivation for responsible innovations, however, is observed that in cluster 1 there are fewer companies with social interests compared to group 2 . In other words, cluster 1 is more technological and less social, while cluster 2 is slightly less technological, but equitable companies oriented towards the social and economic aspects. In comparative analysis, clusters 3 and 4 have a greater inclination towards economic aspects. At last, in cluster 4, there is zero interest in social issues, an attribute that distinguishes it from the rest of the groups.

Regarding clusters that are supported for the business incubation of innovations, it was observed that in cluster 1 about half of the companies have some stimulus. In clusters 3 and 4 , most of them do not receive stimuli and cluster 4 completely does not have any support. Despite this situation, $68 \%$ of SMEs in cluster 1 are considered to have "enough" financial results generated from innovations implemented, followed by clusters 3 and 4, while cluster 2 is characterized by failure to observe any of these good results, since $62 \%$ mentioned that they are few and $38 \%$ perceived outcomes are null. 
An important situation is the lack of methods to measure the results of responsible innovations. In all clusters, more than $50 \%$ of companies do not have any mechanism for this purpose. The results are articulated with business incubation support and financial results that could be inferred that there is a relationship between such features.

Table 8. Characteristics of clusters (percentage values).

\begin{tabular}{|c|c|c|c|c|c|c|}
\hline Attribute & Response & $\begin{array}{l}\text { Cluster } 1 \\
(n=50)\end{array}$ & $\begin{array}{l}\text { Cluster } 2 \\
(n=21)\end{array}$ & $\begin{array}{l}\text { Cluster } 3 \\
(n=19)\end{array}$ & $\begin{array}{l}\text { Cluster } 4 \\
(n=10)\end{array}$ & $\begin{array}{l}\text { General } \\
(n=100)\end{array}$ \\
\hline \multirow{4}{*}{$\begin{array}{l}\text { Motivation that leads to } \\
\text { responsible innovation } \\
\text { (INN_MOT) }\end{array}$} & 1. No response & 0 & 9.5 & 0 & 0 & 2 \\
\hline & 2. Economic result & 28 & 23.8 & 63.2 & 60 & 37 \\
\hline & 3. Social result & 16 & 23.8 & 5.3 & 0 & 14 \\
\hline & 4. Technological result & 56 & 42.9 & 31.6 & 40 & 47 \\
\hline \multirow{2}{*}{$\begin{array}{l}\text { Support for responsible innovation } \\
\text { incubation (INC_SUPP) }\end{array}$} & 1. Yes & 48 & 28.6 & 10.5 & 0 & 32 \\
\hline & 2. No & 52 & 71.4 & 89.5 & 100 & 68 \\
\hline \multirow{3}{*}{$\begin{array}{l}\text { Improvement of financial results } \\
\text { by the implementation of } \\
\text { innovation (FINAN_RES) }\end{array}$} & 1. Many & 68 & 0 & 57.9 & 60 & 64 \\
\hline & 2. Few & 24 & 61.9 & 36.8 & 30 & 30 \\
\hline & 3. Nothing & 8 & 38.1 & 5.3 & 10 & 6 \\
\hline \multirow{2}{*}{$\begin{array}{l}\text { Method to measure the result of } \\
\text { innovation (RES_MET) }\end{array}$} & 1. Yes & 46 & 28.6 & 36.8 & 40 & 40 \\
\hline & 2. No & 54 & 71.4 & 63.2 & 60 & 60 \\
\hline \multirow{2}{*}{$\begin{array}{l}\text { Member of a chamber or business } \\
\text { association (ENTER_ASOC) }\end{array}$} & 1. Yes & 50 & 61.9 & 57.9 & 70 & 56 \\
\hline & 2. No & 50 & 38.1 & 42.1 & 30 & 44 \\
\hline \multirow{2}{*}{ Quality recognition (QUA_REC) } & 1. Yes & 54 & 71.4 & 57.9 & 50 & 58 \\
\hline & 2. No & 46 & 28.6 & 42.1 & 50 & 42 \\
\hline \multirow{2}{*}{ Supplier big companies (SUPP) } & 1. Yes & 64 & 71.4 & 52.6 & 80 & 65 \\
\hline & 2. No & 36 & 28.6 & 47.4 & 20 & 35 \\
\hline \multirow{2}{*}{ Exportation activities (EXPOR) } & 1. Yes & 36 & 38.1 & 47.4 & 30 & 38 \\
\hline & 2. No & 64 & 61.9 & 52.6 & 70 & 62 \\
\hline
\end{tabular}

Moreover, cluster 4 stands out for being integrated in supplier chains of large enterprises (70\%) and belonging to a chamber or business association $(80 \%)$. While cluster 2 is shaped by companies with the highest percentage of enterprises with recognition of their quality $(71.4 \%)$, cluster 3 is the type where more entities with export activities are carried out (47.4\%). Finally, cluster 1 is a combination of companies with these attributes.

\subsection{Type of Organizations to Drive Responsible Innovation}

Once analysed the levels of social entrepreneurship intentions and the characteristics of enterprises, clusters can be configured according to models of organizations to try to conduct responsible innovation:

Cluster 1: Techno-Scientific Model (50\% of SMEs), this model has the highest level of social entrepreneurship intentions with a strong conviction to change, being aware of morality and being inspired by other activists to reduce social and environmental problems through the optimal use of technologies. Technological aspects are its main motivation when it comes to the development of a responsible innovation, receiving support for this purpose. It is a group where financial results are perceived in different magnitudes, thanks to their efforts to have some method for its measurement.

Cluster 2: Techno-Social Model (21\% of SMEs), this type of organization sustains its quality through awards and certifications. Is not inspired by the success stories of innovations and networks of entrepreneurs, but is moved by the social and economic outcomes. It is common to receive stimuli for the development of responsible innovations, which lies in the perception of poor financial results, although they have fewer mechanisms or methods for measuring such results.

Cluster 3: Capitalist-Social Model (19\% of SMEs), this kind of enterprise stands out for its activities of export and being guided by economic outcomes. Its social entrepreneurship intentions are moderate, where the study and implementation of technologies take place and are indispensable for the generation and development of a responsible innovation. It is characterized by a lack of concern for whether their ethics are challenged by others, and are not moved by the decrease in environmental 
problems. A few companies can receive support but it is not necessary. These companies have benefited from financial results by innovations implemented, although instruments to measure them are not an activity for the majority of SMEs.

Cluster 4: Capitalist model (10\% of SMEs), this model belongs to associations, companies interested in economic performance, providers of large enterprises with the absence of social motives. For this reason, the level of social entrepreneurship is 'poor' and there lacks change and social commitment-oriented motivations. In addition to this, it is a group that does not receive any kind of resource, or support for the development of responsible innovations. Apart from a few efforts, most SMEs do not have mechanisms of measurement to assess their economic results, however most of them, recognize some financial benefit, implying that they are conducted under other aspects that are far away from the social entrepreneurship.

\section{Discussion}

The results suggest that responsible innovation requires certain additional motivations apart from desire and feasibility of the change, empathy with social needs and a sense of morality. In this sense, responsible innovation finds its potential in the business, technological and academic abilities of entrepreneurs.

Within the sample subject of study, $95 \%$ of entrepreneurs, have higher education and $50 \%$ have done postgraduate studies. In addition, $61 \%$ refer to having information about business. The results obtained allow us to identify that in Mexico, entrepreneurs mainly develop responsible innovations driven by enthusiasm in developing its business, technological and academic abilities being the "Techno-Scientific" model the greatest affinity possible to Mexican entrepreneurs.

The main driver for the "Techno-Scientific model" is the strong conviction that social problems can be solved with the optimal technological arrangement and thus tend to obtain foundation support. Although emotional empathy does not influence their motivations in a decisive way, SMEs under this model, found the problems of others, as a source that has an impact on their creativity to develop sophisticated technologies. In general, they have generated a connection articulating scientist capabilities around the solution of problems and specific challenges of society, which found root on priority needs of the country. By this, support of social activists or scientist networks is important to inspire other entrepreneurs to create and develop focused innovations.

From the Mexican specific experience, this study has provided evidence related to, responsible innovations within an SME context and can be conducted through different organizational models, even isolated from institutional systems such as the "Techno-Social" model. This finding contradicts European approaches relating to responsible innovation representing a challenge that must be tackled in a collective way and foundationally and require workable relationships with a complex network of stakeholders [60]. Beyond, this study gives light about the existence of a type of SME that prefers to build its own path as a symbol of leadership in the field of responsible innovation. The "Techno-Social" model, although not usually inspired by success stories of other innovations or through networks of entrepreneurs, sustains its responsible innovations motivated by the explicit desire of obtaining economic benefits and developing and implementing technologies that add value to society. This simultaneous three-dimensional desire compels the integration of responsibility in central business strategy.

Identification of different models of organization to conduct solutions to social problems, can add elements that change the logic of discussion, particularly with arguments supported by current social entrepreneurship researchers, to consider that the non-profit model is the model of a distinctive organization that embodies social entrepreneurship. In these terms, this study contends that a business initiative which is intended to create social value, might accept in the same level of priority, other kinds of expectations, such as techno-scientific progress and economic results. As explained in the previous section, these attributes are configured in the "Techno-Social" model singular organization 
that could embody more accurately the phenomenon of responsible innovation in the context of specific Mexican SMEs.

This study aims to not only focus on theory-building, but also provide practical substance to inform and encourage entrepreneurs as practitioners who would like to engage in responsible innovation from a local reality. It would open the discussion of what responsible innovation means toward how it could be implemented in a specific business context to a broader set of empirical context.

\section{Conclusions}

The concept of responsible innovation implies that the innovative process design, is necessary to ensure its positive impact on society. From Europe proclaimed proposals, rules and governing processes have been established, however, responsibility interest is not exclusive of a geographic location or a specific organization type. Therefore, any responsible innovation framework should be critically assessed before being implemented in a particular innovation context, especially for innovation context beyond the European borders [5].

Unlike common innovations, the responsible innovation is the result of various reasons or sources of inspiration that influences the decisions of creativity of entrepreneurs to conduct and generate innovations to solve problems of the society. Interestingly, entrepreneurs seeking to create social ventures are found to have higher levels of entrepreneurial self-efficacy and more ambitious goals than their commercial counterparts [87]

Moreover, research on the individual level of analysis typically focuses on the intention to engage entrepreneurs but not on the actual launch of a social venture. This implies that the analysis needs to look beyond the individual level and considerer the links to the organization level [88].

The first issues that need to be clarified are what forms of responsible venture exist? And what type of conflict do they cause? By a typology, it is possible to differentiate responsible innovation ventures in terms of their business model and, thus, the level of tension between social, technological and economic value creation. More research is required that systematically links the choice of a venture model not only to the legal form [89] and organizational design [90] but to the appropriate management model as well.

Through the statistical technique of cluster analysis, this study identified and characterized four groups of companies according to the level of social entrepreneurship intentions that has led them to the generation and development of responsible innovation. Each group represents a "model of organization" which has a different focus and are summarized as follows (Table 9):

Table 9. Organizational model based on social entrepreneurship.

\begin{tabular}{cc}
\hline Organizational Model & Approach \\
\hline Techno-scientific model & More technological than social \\
Techno-social model & Technological, social and economic \\
Capitalist-social model & More economic than social \\
Capitalist model & Totally economic \\
\hline
\end{tabular}

Despite the fact that this quantitative study has utilized a homogenous sample of SMEs conducting RI, it has been able to differentiate between various configurations of organization models proving that exist more than one path for these Mexican SMEs to achieve RI. Our study may encourage the choice to engage RI to understand a new market based organizational form that is designed for the explicit purpose of resolving social problems.

While in Europe the dominant discourse about responsible innovation focuses on the control of the risk of social rejection of the advancement of science and technology. In contexts such as in Mexico, the phenomenon of responsible innovation is configured as the mechanism through which entrepreneurs articulate its technological and scientific capabilities around solving priority and specific problems of the society, even though, the social impact does not crucially affect their business initiatives. 
"Techno-Scientific" model ( $50 \%$ of studied SMEs) is proposed as the model of organization with greater viability for Mexican examined entrepreneurs. This discovery contrasts the results obtained in a previous study of 15 SMEs in different Nordic countries, which reported as intentions mostly adopted by social entrepreneurs, the desire to positively impact society and generate economic benefits are prioritized as business goals at the same level [12].

At another level, the choice of a particular business model to conduct RI represents a specific constellation of decision-making rights by combining different resources available and coordinates actions in a singular way. To further research, we advocate scrutiny in order to better understand the potential for such innovation by SMEs.

We admit that because a non-probabilistic sample was analysed the results of research cannot be interpreted as the results of Mexican enterprises, but only as the results of Mexican enterprises participating in the study. Nonetheless, this finding may contribute to the articulation of efforts to establish platforms and develop scaffolding between "responsible entrepreneurs" agenda and "strategic programs" aligned objectives of sustainable development rooted in the priority social needs of any country, to promote convergence between entrepreneurs and place of competition.

With the exploratory nature of this work, reduced sample size study and transversal cutting, longitudinal studies, are proposed as future lines of research to draw conclusions of the phenomenon in this other sense. As well as researches around to variables that are related to motivation, with respect to the priority, sequencing, and interplay of these motivations, examining the configuration of multiple intentions and how they impact in cost effectiveness and social value within the innovation process. Furthermore, being a descriptive study, is recommended to support in a better way the results with confirmatory statistical techniques.

Author Contributions: I.L.B.-Á. is the leading author of this study, contributed to the study design, the conceptual analysis for the framework used in this review, and final writing of the article. A.D.-C., was predominantly involved in study methodology, specifically in Statistics assessment and the synthesis of the results. E.C.-P. was involved in the overall supervision of the evaluation of the quality of the study.

Funding: This work was supported by the Ministry of Science and Innovation under Grant ECO2017-88222-P.

Conflicts of Interest: The authors declare no conflict of interest. 
Appendix A. Dendrogram of SMEs According to Their Social Entrepreneurship Intentions

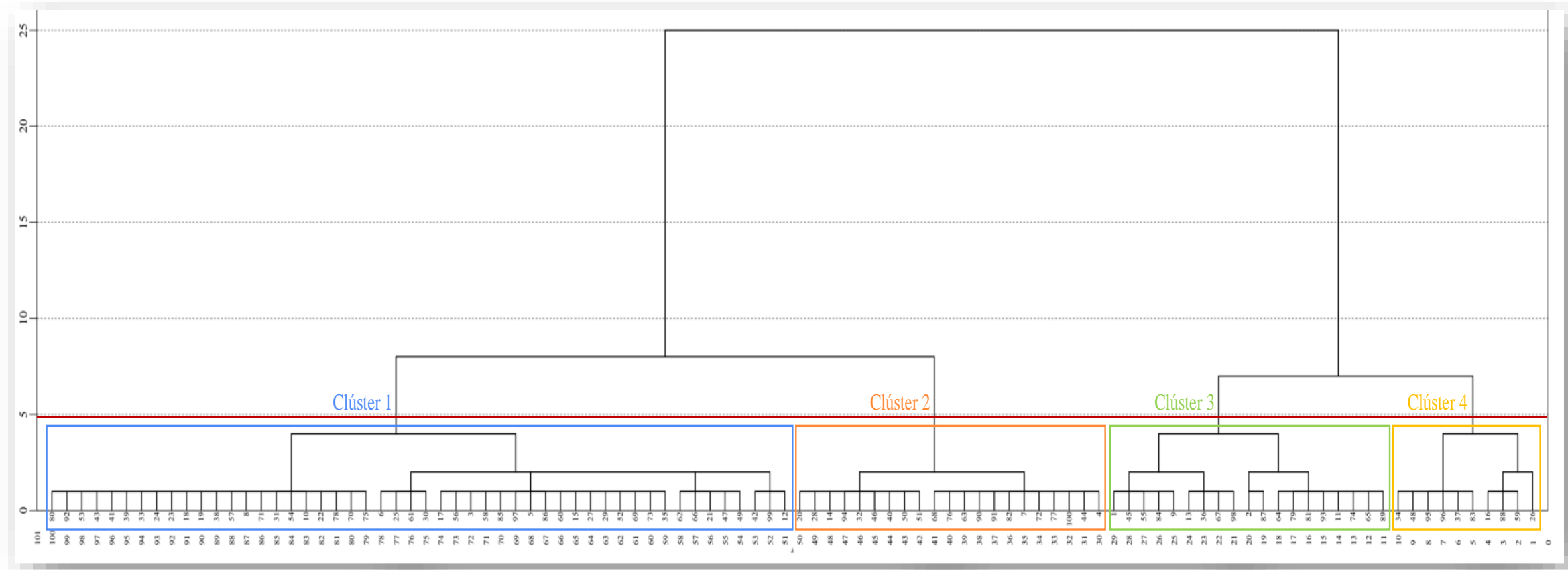




\section{References}

1. European Commission. Available online: https:/ec.europa.eu/spain/actualidad-yprensa/noticias/ investigación-desarrollo-e-innovacion/horizonte2020_es.htm (accessed on 3 March 2017).

2. Burget, M.; Emanuele, B.; Margus, P. Definitions and conceptual dimensions of responsible research and innovation: A literature review. Sci. Eng. Ethics 2017, 23, 1-19. [CrossRef] [PubMed]

3. Lettice, F.; Pawar, K.; Rogers, H. Responsible innovation: What challenges does it pose for the new product development process. In Proceedings of the 19th International Concurrent Enterprising (ICE) Conference, The Hague, The Netherlands, 24-26 June 2013.

4. Pellé, S.; Reber, B. Responsible Innovation Models Report; Current Theory and Practice. Available online: http://www.greatproject.eu/research/Responsible_Innovation_Model_Report_versionforsubmission. docx (accessed on 20 June 2019).

5. Lubberink, R.; Blok, V.; Van Ophem, J.; Omta, O. Lessons for responsible innovation in the business context: A systematic literature review of responsible, social and sustainable innovation practices. Sustainability 2017, 9, 721. [CrossRef]

6. Brammer, S.; Hoejmose, S.; Marchant, K. Environmental management in SMEs in the UK: Practices, pressures and perceived benefits. Bus. Strat. Env. 2012, 21, 423-434. [CrossRef]

7. Chell, E.; Nicolopoulou, K.; Karataş-Özkan, M. Social entrepreneurship and enterprise: International and innovation perspectives. Entrep. Reg. Dev. 2010, 22, 485-493. [CrossRef]

8. Klewitz, J.; Hansen, E. Sustainability-oriented innovation of SMEs: A systematic review. J. Clean. Prod. 2014, 65, 57-75. [CrossRef]

9. Vargas-Martínez, E.E.; Bahena-Álvarez, I.L.; Cordón-Pozo, E. Innovación responsable: Nueva estrategia para el emprendimiento de mipymes. Innovar 2018, 28, 41-53. [CrossRef]

10. Mair, J.; Marti, I. Social entrepreneurship research: A source of explanation, prediction, and delight. J. World Bus. 2006, 41, 36-44. [CrossRef]

11. Shapero, A.; Sokol, L. The social dimensions of entrepreneurship. Available online: https://ssrn.com/abstract= 1497759 (accessed on 6 July 2019).

12. Hockerts, K.; Morsing, M.; Eder-Hansen, J.; Krull, P.; Midttun, A.; Halme, M.; Sweet, S.; Davidsson, P.; Sigurjónsson, T.; Nurmi, P. CSR-Driven Innovation: Towards Social Purpose Business, 2008. Available online: http://www.samfundsansvar.dk/graphics/Samfundsansvar.dk/csrinnovation/Dokumenter/csr-direport_final.pdf (accessed on 20 September 2010).

13. Boschee, J. Social entrepreneurship. Across Board 1995, 32, 20-25.

14. Henton, D.; Melville, J.; Walesh, K. The age of the civic entrepreneur: Restoring civil society and building economic community. Nat. Civ. Rev. 1997, 86, 149-156. [CrossRef]

15. Bornstein, D. Changing the world on a shoestring. Atlant. Mon. 1998, 281, 34-38.

16. Brinckerhoff, P.C. Social Entrepreneurship: The Art of Mission-Based Venture Development; John Wiley and Sons: New York, NY, USA, 2000.

17. Dees, J.G.; Emerson, J.; Economy, P. Enterprising Nonprofits: A Toolkit for Social Entrepreneurs; John Wiley and Sons: New York, NY, USA, 2001.

18. Drayton, W. The citizen sector: Becoming as entrepreneurial and competitive as business. Calif. Manag. Rev. 2002, 44, 120-132. [CrossRef]

19. Leadbeater, C. The Rise of the Social Entrepreneur; Demos: London, UK, 1997.

20. Warwick, D. Will social entrepreneurs blossom or hit bottom? People Manag. 1997, 3, $20-56$.

21. Zadek, S.; Thake, S. Send in the social entrepreneurs. New Statesman 1997, 126, 31.

22. SSE Background. Available online: http://www.sse.org.uk/network/index.shtml (accessed on 16 March 2016).

23. Haugh, H. Social enterprise: Beyond economic outcomes and individual returns. In Social Entreprise; Palgrave Macmillan: London, UK, 2006. [CrossRef]

24. Light, P.C. Reshaping social entrepreneurship. Stanford Soc. Innov. Rev. 2006, 4, 47-51.

25. Mair, J.; Robinson, J.; Hockerts, K. Social Entrepreneurship; Palgrave Macmillan: New York, NY, USA, 2006. [CrossRef]

26. Hockerts, K. Managerial Perceptions of the Business Case for Corporate Social Responsibility; CBS Center for Corporate Social Responsibility: Frederiksberg, Denmark, 2007. 
27. Robinson, J.; Blockson, L.; Robinson, S. Exploring stratification and entrepreneurship: African American women entrepreneurs redefine success in growth ventures. Ann. Am. Acad. Polit. Soc. Sci. 2007, 613, 131-154. [CrossRef]

28. Austin, J.; Stevenson, H.; Wei-Skillern, J. Social and commercial entrepreneurship: Same, different, or both? Rev. de Administração 2012, 47, 370-384. [CrossRef]

29. Merging Mission and Money: A Board Member's Guide to Social Entrepreneurship. Available online: http://www.socialent.org/pdfs/MergingMission.pdf (accessed on 14 March 2018).

30. Sagawa, S.; Segal, E. Common interest, common good: Creating value through business and social sector partnerships. Calif. Manag. Rev. 2000, 42, 105-122. [CrossRef]

31. Waddock, S.A. Building successful social partnerships. MIT Sloan Manag. Rev. 1988, 29, 17.

32. Alvord, S.H.; Brown, L.D.; Letts, C.W. Social entrepreneurship and societal transformation: An exploratory study. J. Appl. Behav. Sci. 2004, 40, 260-282. [CrossRef]

33. Defourny, J.; Nyssens, M. Social enterprise in europe: Recent trends and developments. Soc. Enterp. J. 2008, 4, 202-228. [CrossRef]

34. Nyssens, M. Social Enterprise-At the Crossroads of Market, Public Policies and Civil Society; Routledge: Abingdon, UK, 2006.

35. ICESEM Working Paper for MEXICO. Available online: https://www.iap-socent.be/sites/default/files/Mexico\% 20-\%20Conde_0.pdf (accessed on 12 June 2019).

36. Nicholls, A. Social Enterpreneurship, New Models of Sustainable Social Change; Oxford University Press: Oxford, UK, 2006.

37. Austin, J.E. The Collaboration Challenge: How Nonprofits and Businesses Succeed through Strategic Alliances; Jossey-Bass: San Francisco, CA, USA, 2000.

38. Foss, N.J.; Saebi, T. Fifteen years of research on business model innovation: How far have we come, and where should we go? J. Manag. 2017, 43, 200-227. [CrossRef]

39. Lepoutre, J.; Justo, R.; Terjesen, S.; Bosma, N. Designing a global standardized methodology for measuring social entrepreneurship activity: The global entrepreneurship monitor social entrepreneurship study. Small Bus. Econ. 2013, 40, 693-714. [CrossRef]

40. Rawhouser, H.; Cummings, M.; Newbert, S.L. Social impact measurement: Current approaches and future directions for social entrepreneurship research. Entrep. Theory Pract. 2019, 43, 82-115. [CrossRef]

41. Miller, T.L.; Grimes, M.G.; McMullen, J.S.; Vogus, T.J. Venturing for others with heart and head: How compassion encourages social entrepreneurship. Acad. Manag. Rev. 2012, 37, 616-640. [CrossRef]

42. Peredo, A.M.; McLean, M. Social entrepreneurship: A critical review of the concept. J. World Bus. 2006, 41, 56-65. [CrossRef]

43. Stevens, R.; Moray, N.; Bruneel, J. The social and economic mission of social enterprises: Dimensions, measurement, validation, and relation. Entrep. Theory Pract. 2015, 39, 1051-1082. [CrossRef]

44. Dacin, P.A.; Dacin, M.T.; Matear, M. Social entrepreneurship: Why we don't need a new theory and how we move forward from here. Acad. Manag. Perspect. 2010, 24, 37-57. [CrossRef]

45. Kania, J.; Kramer, M. Collective Impact. Available online: https://scholar.google.com/scholar?hl=es\&as_sdt= 0\%2C5\&q=Kania $\% 26+$ Kramer\%2C $+2011 \& b \operatorname{tnG}=$ (accessed on 28 June 2019).

46. Liston-Heyes, C.; Ceton, G. An investigation of real versus perceived CSP in S\&P-500 firms. J. Bus. Ethics 2009, 89, 283-296. [CrossRef]

47. de Salazar, J.; Husted, B.W.; Biehl, M. Thoughts on the evaluation of corporate social performance through projects. J. Bus. Ethics 2012, 105, 175-186. [CrossRef]

48. Marom, I.Y. Toward a unified theory of the CSP-CFP link. J. Bus. Ethics 2006, 67, 191-200. [CrossRef]

49. Brickson, S. Organizational identity orientation: The genesis of the role of the firm and distinct forms of social value. Acad. Manag. Rev. 2007, 32, 864-888. [CrossRef]

50. Baregheh, A.; Rowley, J.; Sambrook, S. Towards a multidisciplinary definition of innovation. Manag. Decis. 2009, 47, 1323-1339. [CrossRef]

51. Vasen, F. Innovación Responsable: Un Marco Aún Demasiado Europeo. Available online: http://www.scidev.net/america-latina/innovacion/opinion/innovacion-responsable-un-marco-aundemasiado-europeo.html (accessed on 15 May 2015). 
52. Von Schomberg, R. Prospects for Technology Assessment in a Framework of Responsible Research and Innovation. Technikfolgen Abschätzen Lehren. VS Verlag für Sozialwissenschaften; Springer Fachmedien: Wiesbaden, Germany, 2012. [CrossRef]

53. Stilgoe, J.; Owen, R.; Macnaghten, P. Developing a framework for responsible innovation. Res. Pol. 2013, 42, 1568-1580. [CrossRef]

54. Genus, A.; Iskandarova, M. Responsible innovation: Its institutionalisation and a critique. Technol. Forecast. Soc. Change 2018, 128, 1-9. [CrossRef]

55. Pavie, X.; Scholten, V.; Carthy, D. Responsible Innovation: From Concept to Practice; World Scientific Publishing Co.: Singapore, 2014.

56. Scholten, V.E.; Van der Duin, P.A. Responsible innovation among academic spin-offs: How responsible practices help developing absorptive capacity. J. Chain Netw. Sci. 2015, 15, 165-179. [CrossRef]

57. Halme, M.; Korpela, M. Responsible innovation toward sustainable development in small and medium-sized enterprises: A resource perspective. Bus. Strat. Environ. 2014, 23, 547-566. [CrossRef]

58. Armstrong, M.; Cornut, G.; Delacôte, S.; Lenglet, M.; Millo, Y.; Muniesa, F.; Tadjeddine, Y. Towards a practical approach to responsible innovation in finance: New product committees revisited. J. Financ. Regul. Compliance 2012, 20, 147-168. [CrossRef]

59. Asante, K.; Owen, R.; Williamson, G. Governance of new product development and perceptions of responsible innovation in the financial sector: Insights from an ethnographic case study. J. Respon. Inno. 2014, 1, 9-30. [CrossRef]

60. Muniesa, F.; Lenglet, M. Responsible innovation in finance: Directions and implications. In Responsible Innovation: Managing the Responsible Emergence of Science and Innovation in Society; Wiley: London, UK, 2013; pp. 185-198.

61. Wodzisz, R. Case Study of R-1234yf refrigerant: Implications for the framework for responsible innovation. Sci. Eng. Ethics 2015, 21, 1413-1433. [CrossRef]

62. Hall, J. Sustainable development innovation; a research agenda for the next 10 years. Editorial for the 10 th Anniversary of the Journal of Cleaner Production. J. Clean. Prod. 2002, 3, 195-196. [CrossRef]

63. Hockerts, K. Sustainability, Innovations Ecological and Social Entrepreneurship and Management of Antagonistic Assets. Ph.D. Thesis, University St. Gallen, Bamberg, Germany, 2003.

64. Wüstenhagen, R.; Sharma, S.; Starik, M.; Wuebker, R. Sustainability, Innovation and Entrepreneurship: Introduction to the Volume; Edward Elgar Publishing: Cheltenham, UK, 2008.

65. Adams, R.; Bessant, J.; Jeanrenaud, S.; Overy, P.; Denyer, D. Innovating for Sustainability: A Systematic Review of the Body of Knowledge; Network for Business Sustainability: London/Montreal, QC, Canada, 2012.

66. Lubberink, R.; Blok, V.; van Ophem, J.; Omta, O. A framework for responsible innovation in the business context: Lessons from responsible-, social- and sustainable innovation. In Responsible Innovation 3: A European Agenda? Asveld, L., van Dam-Miras, M.E.C., Swierstra, T., Lavrijssen, S.A.C.M., Linse, C.A., van den Hoven, J., Eds.; Springer: Dordrecht, The Netherlands, unpublished work.

67. Adams, R.; Jeanrenaud, S.; Bessant, J.; Denyer, D.; Overy, P. Sustainability-oriented innovation: A systematic review. Int. J. Manag. Rev. 2016, 18, 180-205. [CrossRef]

68. Franceschini, S.; Faria, L.G.D.; Jurowetzki, R. Unveiling scientific communities about sustainability and innovation. A bibliometric journey around sustainable terms. J. Clean. Prod. 2016, 127, 72-83. [CrossRef]

69. Tukamushaba, E.K.; Orobia, L.; George, B.P. Development of a conceptual model to understand international social entrepreneurship and its application in the Ugandan context. J. Int. Entrep. 2011, 9, 282-298. [CrossRef]

70. Forster, F.; Grichnik, D. Social entrepreneurial intention formation of corporate volunteers. J. Soc. Entrep. 2013, 4, 153-181. [CrossRef]

71. Ernst, K. Heart over Mind-An Empirical Analysis of Social Entrepreneurial Intention Formation on the Basis of the Theory of Planned Behavior. Ph.D. Thesis, Universität Wuppertal, Fakultät für Wirtschaftswissenschaft/Schumpeter School of Business and Economics, Wuppertal, Germany, 2018.

72. Hockerts, K. Determinants of social entrepreneurial intentions. Entrep. Theory Pract. 2017, 41, 105-130. [CrossRef]

73. Panorama de la Educación 2017. Available online: http://www.oecd.org/education/skills-beyond-school/ EAG2017CN-Mexico-Spanish.pdf (accessed on 21 June 2019).

74. Zahra, S.A.; Gedajlovic, E.; Neubaum, D.O.; Shulman, J.M. A typology of social entrepreneurs: Motives, search processes and ethical challenges. J. Bus. Ventur. 2009, 24, 519-532. [CrossRef] 
75. Stephan, U.; Uhlaner, L.M.; Stride, C. Institutions and social entrepreneurship: The role of institutional voids, institutional support, and institutional configurations. J. Int. Bus. Stud. 2015, 46, 308-331. [CrossRef]

76. Bos-Brouwers, H.E.J. Corporate sustainability and innovation in SMEs: Evidence of themes and activities in practice. Bus. Strat. Environ. 2010, 19, 417-435. [CrossRef]

77. Byrne, B.M. Structural Equation Modeling with Mplus: Basic Concepts, Applications, and Programming; Routledge: New York, NY, USA, 2013.

78. Wang, J.; Wang, X. Structural Equation Modeling: Applications using Mplus; John Wiley \& Sons: Chichester, UK, 2012.

79. Finney, S.J.; DiStefano, C.H. Nonnormal and categorical data in structural equation modeling. In Structural Equation Modeling. A Second course; Information Age Publishing. Inc.: Charlotte, NC, USA, 2006.

80. Muthén, B.; du Toit, S.H.C.; Spisic, D. Robust Inference using Weighted Least Squares and Quadratic Estimating Equations in Latent Variable Modeling with Categorical and Continuous Outcomes; University of Califormia: Los Angeles, CA, USA, 1997; Available online: http://www.statmodel.com/bmuthen/articles/Article_075.pdf (accessed on 16 February 2019).

81. Hair, J.F.; Black, W.C.; Babin, B.J.; Anderson, R.E. Multivariate Data Analysis, 7th ed.; Pearson Education Limited: London/Essex, UK, 2014.

82. Bagozzi, R.P.; Yi, Y.; Phillips, L.W. Assessing construct validity in organizational research. Admin. Sci. Q. 1991, 36, 421-458. [CrossRef]

83. Cormack, R.M. A review of classification. J. Roy. Stat. Soc. 1971, 134, 321-367. [CrossRef]

84. Everitt, B.; Landau, S.; Leese, M.; Stahl, D. Cluster Analysis, 5th ed.; John Wiley \& Sons: London, UK, 2011. [CrossRef]

85. Ward, J.H. Hierarchical grouping to optimize an objective function. J. Am. Stat. Assoc. 1963, 58, $236-244$. [CrossRef]

86. DOF. Acuerdo por el que se Establece la Estratificación de las Micro, Pequeñas y Medianas Empresas. Mexico: Diario Oficial de la Federación. Available online: http://dof.gob.mx/nota_detalle.php?codigo=5096849\& fecha=30/06/2009 (accessed on 14 July 2017).

87. Clark, K.D.; Newbert, S.L.; Quigley, N.R. The motivational drivers underlying for-profit venture creation: Comparing social and commercial entrepreneurs. Int. Small Bus. J. 2018, 36, 220-241. [CrossRef]

88. Perrini, F.; Vurro, C.; Costanzo, L.A. A process-based view of social entrepreneurship: From opportunity identification to scaling-up social change in the case of San Patrignano. Entrep. Reg. Dev. 2010, 22, 515-534. [CrossRef]

89. Haigh, N.; Kennedy, E.D.; Walker, J. Hybrid organizations as shape-shifters: Altering legal structure for strategic gain. Calif. Manag. Rev. 2015, 57, 59-82. [CrossRef]

90. Santos, F.; Pache, A.C.; Birkholz, C. Making hybrids work: Aligning business models and organizational design for social enterprises. Calif. Manag. Rev. 2015, 57, 36-58. [CrossRef] 